811.161.1'276.6:338.48

371.671.046.16:811.161.1'243(497.11) https://doi.org/10.18485/sj.2018.23.1.36

ЈЕЛЕНА Ј. МИХАЈЛОВИЪ *

Паневропски универзитет „Апеирон”

Факултет филолошких наука

Бања Лука
Оригинални научни рад

Примљен: 04. 01. 2018.

Прихваћен: 29. 01. 2018.

\title{
ФОРМИРАњЕ ЛЕКСИКЕ ТУРИЗМОЛОШКОГ ПРОФИЛА ИЗ ОПШТЕГ ЛЕКСИЧКОГ ФОНДА РУСКОГ ЈЕЗИКА
}

(у примени на савремени уџбеник руског језика високошколске туризмолошке струке и њему сродне уџбенике)

Циљ овог рада јесте покушај да се прикаже семантичка виталност речи, тј. њихово кретање и преобликовање из општег лексичког фонда руског језика ка лексици туризмолошке струке. На тај начин оне налазе своју примену у савременим уџбеницима руског језика високошколске туризмолошке струке.

Кључне речи: семантичка виталност речи и њихова трансформација, комуникативна функција језика, општи лексички фонд руског језика, речник руског језика и речничка лексика, српски преводни еквиваленти, лексика туризмолошке струке, уџбеник руског језика високошколске туризмолошпке струке.

Како бисмо се бавили питањем формирања лексике туризмолошке струке из општег лексичког фонда руског језика, потребни су нам речници руског језика таквог профила који подразумевају извесну лексичку свеобухватност. Поред бројних коришћених речника и њихове примене у нашим конкретним истраживањима, у овом делу проучавања лексичког аспекта главни оријентир нам је «Основни руско-српскохрватски речник» (Р. Маројевић, М. Маројевић, В. О. Можајева, 1985).

*jelena1952@gmail.com 
Из увода речника се запажа, да је њиме «обухваћена лексика савременог руског језика која је неопходана за комуницирање у званичним и свакодневним ситуацијама, за читање текстова средње тежине у новинама, часописима и из белетристике, за разумевање радио и телевизијских емисија и сл.». Даље, из увода се види да речник има «5000 најфреквентнијих и најактуелнијих речи савременог руског књижевног језика, велики број говорних конструкција, типичних за савремени руски језик, као и најфреквентније устаљене изразе» (Маројевић, Маројевић, Можајева 1985: 5).

С обзиром на то да је за наше истраживање веома важна улога комуникативне функције језика у домену туризмолошке струке (Михајловић 2012: 235-244), речник са лексиком која је подесна за комуницирање у званичним и свакодневним ситуацијама је веома актуелан, те се може активно користити и у истраживању коришћења лексичких јединица у разним стручним доменима, међу њима и у туризмолошкој области. Бројне лексичке одреднице, синтагме, фразеолошке јединице, говорне конструкције из савременог руског књижевног језика потврђују његову актуелност у свакодневној, социокултурној и сфери одређене струке.

Коришћење лексике из општег фонда руског језика је првенствено намењено оним полазницима који никада нису учили руски језик, наравно и онима који су га учили, те на тај начин обнављају свој лексички фонд и стварају оптималну базу лексичког знања. Томе у првом реду доприноси и сама структура речника, која није базирана само на руској речи-одредници и њеном преводу, већ су дате и граматичке карактеристике руске речи, примери употребе руске речи и превод тих примера, а после свих значења чак се дају и устаљени израз.

Ради јаснијег приказа распона свеобухватности речничке лексике покушаћемо да путем његових одредница квалификујемо профил високошколског уџбеника руског језика туризмолошког смера, који представља почетни ниво учења, као и њему сродних уџбеника. Таква координираност је омогућена самом наменом и уџбеника и речника.

Речник је намењен свима који почињу самостално или уз помоћ наставника да уче руски језик. Уџбеник руског језика економско-туристичко-угоститељског смера (Михајловић, 2007) подразумева почетни ниво, који у својој широј намени програмски покрива 6 семестара учења на Високој туристичкој школи и другим сродним високим школама и факултетима сходно програмској оријентацији. Интензификација уџбеничке грађе преко семестралних нивоа управо јесте пут профилисања лексике од општег поимања руског језика у виду свакодневних животних реалија, преко социокултурних до ужестручних датости. 
Први део уџбеника за Руски језик (Михајловић, 2007, стр: 5) под називом Аутобиография, знакомство, встречи - Аутобиографија, упознавање, сусре$m и$ добрим делом се заснива на општем садржају лекција. Примери лексике општег карактера нам најбоље документују поменути садржај:

\footnotetext{
знакомств $\| \mathbf{0 , - a}$ c 1. с кем упознавање; познанство; о студентов с преподавателем упознавање студената са професором; поддерживать, прекращать о $с$ кем одржавати, прекидати познанство с ким 2. с чем упознавање; познавање, знање чега; о с русской литературой познавање руске књижевности (Маројевић, Маројевић, Можајева, 1985: стр. 87).
}

Иако ова лексичка одредница стоји у наслову поглавља уџбеника, она се даље као таква не користи у тексту лекције. Врло је важна на самом почетку учења руског језика јер одређује релацију знакомства преподавателя $c$ студентами као и студентов с преподавателем као и знакомство с руской литературой. Паралелно са овом глаголском именицом, уводи се уз помоћ поменутог речника (стр. 174) и глагол познакомиться.

познаком\|иться, -люсь, -ишься, -ятся сври. 1. с кем и без. обј. упознати се $с$ ким, упознати кога; они ились в экспедиции они су се упознали за време експедиције 2. $c$ чем упознати се $c$ чим, упознати ита; иться с условиями жизни кого упознати се са чијим животним условима (несври. знакомиться).

У контексту представљања како стоји у уџбенику (Михајловић, 2007, стр. 5):

Разречите представиться.Меня зовут...
Я хочу представить вам моего друга. Его зовут....
Я хочу представить вам мою подругу. Её зовут...

могуће је у ове реченичне конструкције увести уместо представиться/представить и варијантну употребу глагола познакомиться/познакомить:

Разрешите познакомиться. Меня зовут <

Я хочу познакомить вас с мочм другом... Его зовут...

Я хочу познакомить вас с моей подругой. Её зовут....

У српском језику такође постоји алтернативна употреба глагола представити/представити се и упознати/упознати се при сусретању, представљању и упознавању:

Дозволите да се представим. Зовем се...

Хоћу да вам представим мога друга. Он се зове..

Хоћу да вам представим моју другарицу. Она се зове ...

Дозволите да се упознамо. Зовем се...

Хоћу да вас упознам са мојим другом... Он се зове...

Хоћу да вас упознам са мојом другарицом. Она се зове...

Из наведених руских примера и њихових српских преводних еквивалената види се да се у великој мери поклапа употреба назначене опште лексике у области говорне етикеције. 
У контексту постављања питања По национальности я кто? и кратких одговора у уџбенику у виду набрајања различитих националности именичким облицима мушког и женског рода, као и множинским обликом:

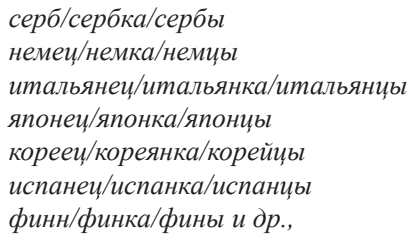

требало би додати именицу мушког рода индеleu,-йu̧a у значењу Индијанац, као и именицу мушког рода инди\|ец, -йца у значењу Индијац. Руска именица женског рода индианка има значење Индијанка и Индијка. Међутим, постоји и именица женског рода индейка са српским значењем ћурка, а индюк је ћуран. Због ових интерферентних појава требало би студентима, нарочито онима на почетном стадијуму учења руског језика, додатно појаснити и ове појмове.

Из истих разлога, у оквиру набрајања различитих националности потребно је навести и руску именицу мушког рода швейцарец у значењу Швајиараи, јер у руском језику постоји и појам швейца́р са значењем вратар, портир, како следи:

«Утром из ды́много ресторана с трудо́м выхо́дит клие́нт:

- Брр! Швейиар! Что то за неприятный запах?

- Это свежий воздух, сэр! » (Михајловић, 2009: стр. 166).

Превод ове пошалице потврђује да је реч швейца́р из лексичког фонда туризмолошке струке у ужем смислу, док сасвим сигурно чини део општег лексичког фонда:

«Ујутро из задимљеног ресторана са муком излази клијент:

- Брр! Портиру! Какав је то непријатан мирис?

- То је свеж ваздух, господине ».

Међутим, у значењу вратар, портир се у текстовима појављује и реч nopmbé, која такође припада лексичком фонду туризмолошке струке. Овде је помињемо због могућности синонимског избора уз лексему швейца́p. То потврђује и пример из изворне уџбеничке литературе руског језика туризмолошког смера, као и његов превод:

«- А наш багаж отнесут в номер? Носильщики здесь есть? - Конечно. С ключом от номера подойдёте к портье и покажете ваши вещи...». (РЭТ-2, 2006: стр. 162);

«-А да ли ће наш пртљаг однети у собу? Да ли овде постоји носач? - Наравно.

Са кључем од собе идите код портира и покажите ваше ствари...».

У делу уџбеника (Михајловић, 2007: стр. 11), где се у поједностављеној схеми приказује руска породица на рођачкој релацији у односу на мужа и жену/супругу: 


\section{Русская семья. Родственные отношения}

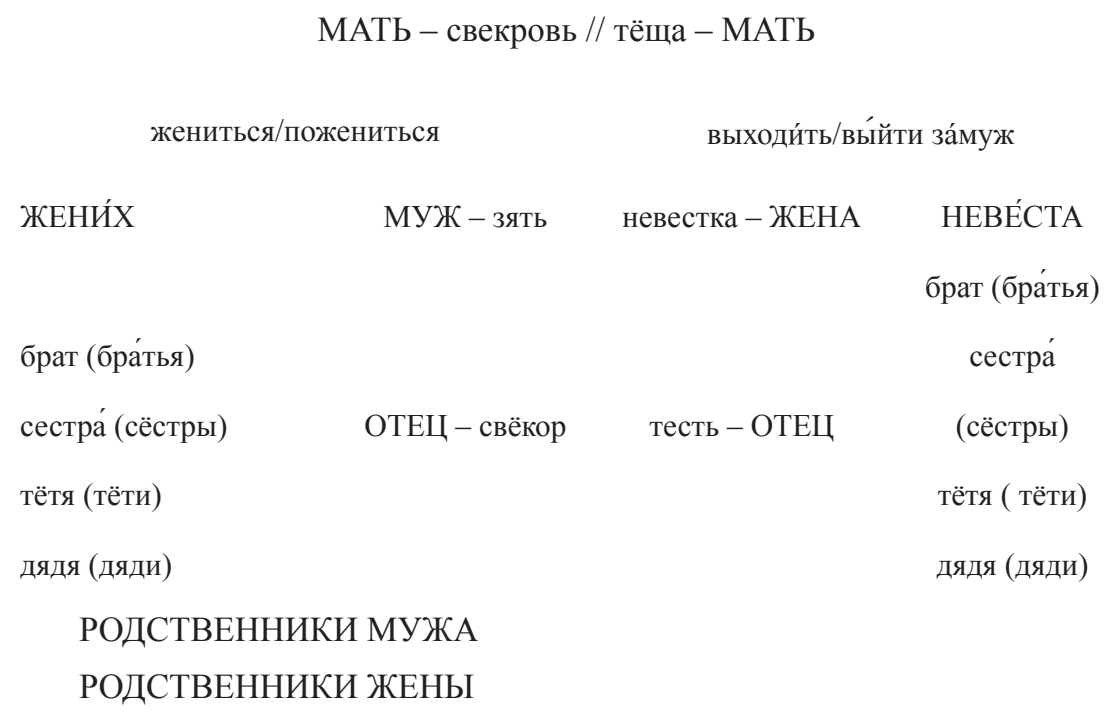

требало би у контексту општег лексичког аспекта појаснити дистинкцију између именица жена́ и же́нщина у руском језику. Речник (Маројевић, Маројевић, Можајева, 1985: стр. 74, 75) нас експлицитно упућује на ово разликовање:

жен\|ĺ, -ы́, $м н$. жёны, жён ж жена, супруга ( $y n$. же́нщина); у него́ молода́я а он има младу жену;

же́нщин\|а, -ы ж жена (yn. жена́); краси́вая, молода́я а лепа, млада жена; пожила́я а жена у годинама; а-врач лекарка.

Координацијом ове две лексичке одреднице у речнику ( $y n$. же́нщина) (yn. женá) се на јасан начин диференцира семантичка вредност између именица жена́ - жена супруга (брачни друг) и же́нщина - жена у општем смислу. Руска именица жена́ у значењу жене у општем смислу има архаичну нијансу (видети Ожегов, 1968: стр. 186).

Из претходних превода на српски језик се види да је именица жена двозначна, тј. и жена у општем смислу (лице по полу супротно мушкарцу, женско) и жена супруга (брачни друг).

Примери из уџбеничке литературе потврђују ову семантичку дистинкцију у руском језику, као и двозначност именице жена у српском језику:

«Моя жена́ просила меня узнать, какой вечер у вас свободен, а она уже согласует с ним своё свободное время». (Николић, Станојевић, 1978: стр.136).

«Моја жена ме је молила да сазнам када имате слободно вече, те ће она своје слободно време уподобити вашем». 
«Нужно помнить, что при разговоре мужчи́ны и же́нщины предложение перейти на ,ты' должно исходи́ть от женщины: это её право выбира́ть характер отношений». (Михајловић, 2007: стр. 15).

«Треба знати, да у разговору мушкарца и жене, иницијатива да се пређе на ,ти' полази од жене: то је њено право да бира карактер опхођења».

Из фонда опште лексике, која чини основно ткање поменутих уџбеника руског језика релевантних за наше истраживање можемо издвојити и реч остано́вка (Маројевић, Маројевић, Можајева, 1985: стр. 149):

Остано́вк $\| \mathbf{a},-\mathbf{- и}$, мн. остано́в $\|$ ки, -ок, -кам ж 1. заустављање, обустављање, обустава, прекид; >а рабо́ты прекид рада; а станка́ заустављање алатне машине 2. прекид, одмор; говори́ть без и говорити без прекида; е́хать без ок ићи не заустављајући се 3. станица ( $y n$. стоя́нка $u$ ста́нция); трамва́йная $\sim$ а трамвајска станица; ждать тролле́йбуса на е чекати тролејбус на станици; а авто́буса ря́дом аутобуска станица је близу; вы выхо́дите на сле́дующей е? излазите ли на следећој станици?

Оваква детаљна обрада семантичког и граматичког значења ове речничке одреднице је за наше истраживање значајна, нарочито у контексту 3. наведеног значења. У том смеру ћемо навести примере из уџбеничке литературе руског језика:

1) «По́езд останови́лся на ма́ленькой ста́нции»:

«Скажи́те, пожа́луйста, далеко́ ли ещё до автомагистра́ли? Где ближа́йшая бензозапра́вочная ста́нция?» (Николић, Станојевић, 1978: стр. 15, 141).

2) «Как мне пройти́ к ста́нции метро́?» (Маројевић 1996: стр. 127).

Ако примере преведемо на српски језик:

1) «Воз се зауставио на малој станици»:

«Кажите, молим вас, да ли има још доста до аутопута? Где је најближа бензинска станица?»;

2) «Како могу да дођем до станице метроа?»,

видимо да руској лексеми од које смо пошли остано́вка одговра у овом конкретном случају руски семантички варијетет ста́нция. На то нас упућује и смерница у оквиру саме речничке одреднице (остано́вка yn. ста́нция), те је српски превод станица сасвим адекватан. Такву руско-српску семантичку корелацију можемо представити остано́вка $\leftrightarrow$ ста́нция $\leftrightarrow$ станица.

Ако се послужимо примерима:

1) «-Скажите, пожа́луйста, где нахо́дится университе́т? - Университе́т недалеко́. Туда́ идёт автобус. - А где остано́вка? - Остано́вка спра́ва. - Спаси́бо». (Милинковић, 1995: стр. 15);

2) «Извините, вы выхо́дите на сле́дующей остано́вке? - Нет, не выхожу́». (Маројевић, 1996: стр. 127);

3) «И сколько остано́вок (мне ну́жно е́хать)? - Всего́ одну́ остано́вку». (Михајловић, 2007: стр. 37) 
и њиховим преводима на српски језик:

1) «- Кажите, молим вас, где се налази универзитет? - Универзитет није далеко. Тамо иде аутобус. - А где је станица? - Станица је десно. - Хвала».;

2)«Извините, да ли излазите на следећој станици? - Не, не излазим»,;

3) «И колико станица треба да идем? - Само једну станицу».

закључујемо да се руска лексема остановка преводи на српски језик речју станица (остано́вка $\leftrightarrow$ станица).

Како бисмо употпунили семантичке варијетете лексичке одреднице остано́вка, на шта нас упућује сам речник у оквиру 3. значења, користићемо се и примерима:

1) «Скажи́те, пожа́луйста, где здесь стоя́нка такси́?» (Раичевић, 2005: стр. 59);

2) «В ка́ждом райо́не го́рода есть стоя́нка такси́». (Маројевић, 1996: стр.127);

као и њиховим преводима на српски језик:

1) «Кажите, молим вас, где је овде такси станица?»;

2) «У сваком реону града постоји такси станица».

И у овим примерима се руска реч стоянка преводи на српски језик речју станица, с тим што у неким контекстима она може значити и стајалиште/ станица; заустављање/паркирање (возила), паркинг, на пример стоянка грузовикбв и m.n. Томе у прилог иде и пример:

«Необходи́мо при гости́ницах организова́ть охраня́емые стоя́нки автомоби́лей или гара́жи...». (Станојевић, Николић, Маројевић, 1979: стр. 40).

У оквиру овог примера синтагма охраня́емые стоя́нки значи паркиралишта која се чувају, те је превод реченице у целости:

«Неопходно је да се при хотелима организују за аутомобиле паркиралишта која се чувају или гараже ... ».

Смерница из речника (Маројевић, Маројевић, Можајева, 1985: стр. 149) уз речничку одредницу остано́вка ( $y n$. стоя́нка $u$ ста́нция) с једне стране указује на полисемичност српске речи станица кроз контекстуалну условљеност, а са друге стране, на варијантне контекстуалне могућности избора једне од три лексеме у руском језику, што се може представити:

станица $\longleftrightarrow$ остано́вка $\leftrightarrow$ стоя́нка $\leftrightarrow$ ста́нция.

Прва (мало дужа) двосмерна стрелица указује на реверзибилан семантички међујезички однос. Друге две (мало краће стрелице) упућују на унутарјезичка семантичка кретања.

Овако представљене лексичке јединице из општег фонда руског језика на унутарјезичком, као и на међујезичком плану добијају извесну динамику, те их можемо класификовати и на овај начин: 
остановка - станица (место заустављања возила за искрцавање и укрцавање путника), стајалиште, на пример остановка автобуса, трамвая, троллейбуса, такси;

станция - станица, на пример железнодорожная, автобусная станция, станция метро, телефонная станция (телефонска централа) и др.;

стоянка - станица, стајалиште; заустављање/паркирање (возила), паркинг, на пример стоянка такси, стоянка грузовиков и др.

Из општег лексичког фонда руског језика издвајамо и глагол останови́ться. У речнику (Маројевић, Маројевић, Можајева, 1985: стр. 149) констатујемо значење ове лексичке одреднице у најширем обухвату, а нарочито у контексту несвршеног и свршеног глаголског облика:

остана́влива | ться, -юсь, -ешься, -ются несври. 1. заустављати се; ться перед ка́ждым до́мом заустављати се испред сваке куће; где ется авто́бус? где стаје аутобус? 2. одседати; ться в гости́нице одседати у хотелу (сври. останови́ться); останов $\|$ и́ться, -лю́сь, остано́в| ишься, -ятся сврш. 1. зауставити се, стати; машина и́лась кола су се зауставила; чась́́ и́лись сат је стао; работа и́лась рад је прекинут 2. одсести; и́ться у родньі́х одсести код рођака (несври. остана́вливаться);

У оквиру првог несвршеног глаголског облика остана́вливаться наводимо неколико примера из уџбеничке литературе са преводима на српски језик:

1) «Четырёхме́стный малолитра́жный автомоби́ль, Москви́ч 407’ остана́вливается на грунтово́й доро́ге во́зле трёх подро́стков... Маши́на остана́вливается. За рулём же́нщина». (Николић, Станојевић, 1978: 141, 143);

1) «Малолитражни аутомобил, четворосед, Москвич-407' се зауставља на колском путу поред три шипарца... Аутомобил се зауставља. За воланом је жена».

2) «Югосла́вская делега́ция остана́вливалась здесь и в про́шлом году́... Машина остана́вливается у гости́ницы». (Маројевић, 1996: стр. 16);

2) «Југословенска делегација је одседала овде и прошле године. ... Аутомобил се зауставља код хотела».

3) «Если судно́ остана́вливается в порту́ на не́которое вре́мя, и пассажи́ры схо́дят на бе́рег, то у них тоже должна́ быть офо́рмлена ви́за». (РЭТ-2, 2006: стр. 124);

3) «Уколико брод пристаје у луку на одређено време и путници излазе на обалу, онда они такође морају да имају визу».

4) «Извините, вы не знаете, где остана́вливается пятнадцатый троллейбус?.. Он остана́вливается напротив концертного зала». (Михајловић, 2007: стр. 35, 37); сале».

4) «Извините, да ли знате где стаје тролејбус бр. 15? ...Стаје прекопута концертне

Из наведених превода на српски језик констатујемо да је руски несвршени глагол остана́вливаться у конкретним примерима углавном у корелацији са значењем 1. из речника. То значи, да сва поменута превозна средства (аутомобил, тролејбус, брод) у једном тренутку прекидају кретање, те се заустављају, стају или пристају, да би потом опет наставили кретање.

Значење глагола остана́вливаться под бројем 2. из речника нам потврђује пример 2) југословенска делегација, која одседа на одређеном месту 
где је већ раније одседала, што упућује на специфичну активност глагола у виду понављања радње.

У оквиру другог свршеног глаголског облика останови́ться наводимо неколико примера из уџбеничке литературе са преводима на српски језик:

1) «По́езд останови́лся на ма́ленькой ста́нции». (Николић, Станојевић, 1978: стр. 15);

1) «Воз је стао на малој станици».

2) «-Ра́зве вы у нас не остано́витесь? - спрашивает администра́тор. - Нет! Пойду́ поищу другую гостиницу». (Милинковић, 1995: стр. 25);

2) «- Зар нећете код нас одсести? - пита рецепционер. - Не! Идем да потражим други хотел».

3) «Вы не торопи́тесь, знакомьтесь с городом... Остано́витесь на не́сколько мину́т. Спроси́те прохо́жего, как пройти́ в ну́жный вам магази́н». (Раичевић, 2005: стр. 81);

3) «Не журите се, упознајте се са градом... Станите/зауставите се на неколико минута. Питајте пролазника, како да дођете до продавнице која вам је потребна».

4) «- Дава́йте посмо́трим вме́сте. Я посмотрю́ катало́ги по Ита́лии и Австрии...

- Это мне не подхо́дит, дава́йте остано́вимся на России... Я остановлю́сь на Кислово́дске. Никогда́ там не был». (РЭТ - 2, 2006: 394);

4) «- Хајде да погледамо заједно. Погледаћу каталоге о Италији и Аустрији...

- То ми не одговара, хајде да се зауставимо на Русији... Одсешћу у Кисловодску. Тамо нисам никада био».

5) « Ита́к, на чём мы останови́лись?... Мы помолча́ли немно́го, а пото́м она останови́лась и спроси́ла когда́ я уезжа́ю». (Михајловић, 2007: стр. 217, 218);

5) «Дакле, где смо оно стали (на чему смо се зауставили)? ... Мало смо ћутали, а затим је она стала и питала када одлазим».

У првом примеру у коме је употребљен свршени глагол останови́ться из превода на српски језик види се поклапање његовог значења са 1. значењем из речника зауставити се, стати.

У другом примеру глагола останови́ться долази до делимичног подударања значења из примера са 2. значењем из речника у делу одсести. То заправо и јесте најважнија преводна одредница за тај руски глагол поред 1. значења стати, зауставити се. Као допуна пример би се у речник, уз значење 2. одсести; и́ться у родных одсести код рођака, могло додати $\sim$ и́ться в гости́нице одсести у хотелу, како то већ стоји у речнику код несвршеног глаголског облика остана́вливаться.

Преводи на српски језик трећег примера указују на корелацију са речничким значењем глагола останови́ться под 1. стати, зауставити се.

У четвртом примеру су употребљена оба значења из речника под 1. зауставити се и под 2. одсести, али у овом случају у Кисловодску као географском појму.

Пети пример у преводу на српски језик у корелацији је са 1. значењем из речника зауставити се, стати, с тим што прва реченица са глаголом остано- 
ви́ьтся у српском језику може имати слојевите семантичке варијанте: Итак, на чём мы останови́лись? Дакле, где смо оно стали? Дакле, на чему смо се зауставили? Дакле, докле смо дошли?

За све ове побројане лексеме кроз руске примере и њихове српске преводне еквиваленте можемо рећи да припадају општем лексичком фонду руског језика:

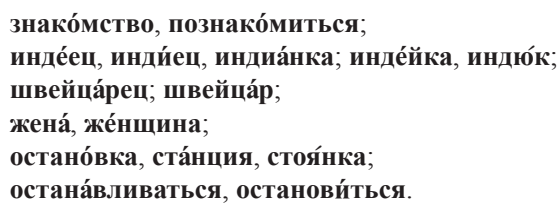

На овом малом лексичком исечку, кога можемо назвати и узорком, покушали смо да укажемо на универзалност језичких средстава. Такође, овакве речи, као и многе друге, из огромне и несамерљиве лексичке ризнице руског језика могу наћи своју примену и у језику туризмолошке струке, на шта смо донекле и овде обратили пажњу.

\section{ИЗВОРИ И ЛИТЕРАТУРА}

Маројевић 1996: М. Маројевић, Руски пословни језик, Београд: Српски лексикограф.

Маројевић Р. - Маројевић М. - Можајева 1985: Р. Маројевић, М. Маројевић, В.О Можајева, Основни руско-српскохрватски речник, Београд: Просвета - Москва: Руски језик.

Милинковић 1995: Љ., Милинковић, Руски језик за економисте са пословном кореспонденцијом, Београд: Савремена администрација.

Михајловић 2007: Ј. Михајловић, Руски језик за факултете и високе школе економско-туристичко-угоститељског смера; почетни ниво учења-интензивни курс, Београд: Завод за уџбенике и наставна средства.

Михајловић 2007: Ј. Михајловић, Руски језик за факултете и високе школе економско-туристичко-угоститељьског; заврини ниво учења, Београд: Завод за уџбенике и наставна средства.

Михајловић 2012: Ј. Михајловић, О месту и улози комуникативне функичје језика у настави руског језика за туризмологе - Београд: МАПРЯЛ, VII Међународни симпозијум, Достигнућа и перспективе конфронтационог проучавања руског и других језика) 235-244. 
PЭТ-2 2006: Л.Б. Трушина, Т.Г. Волкова, Н.Б. Глива, М.И. Лайкова, Е.М. Орлова, К.В. Терентьева, РЭТ-2, Учебный комплекс по русскому языку как иностранному в сфере международного туристского бизнеса, Москва: Издательство ИКАР.

Ожегов 1968: С.И. Ожегов, Словарь русского языка, Москва: Издательство Советская энциклопедия.

Николић-Станојевић 1978: В. Николић, Р. Станојевић, Руски пословни језик, Београд: Савремена администрација.

Раичевић 2005: В. Раичевић, Руски језик за пословне људе у области спољне трговине и туризма, Београд: Institute of economic diplomacy.

Станојевић-Николић-Маројевић 1979: Р. Станојевић, В. Николић, М. Маројевић, Руски језик у угоститељству и туризму, Београд: Виша економска школа.

\section{ФОРМИРОВАНИЕ ЛЕКСИКИ ТУРИЗМОЛОГИЧЕСКОГО ПРОФИЛЯ ИЗ ЛЕКСИЧЕСКОГО ЗАПАСА РУССКОГО ЯЗЫКА В ПРИМЕНЕНИИ К СОВРЕМЕННОМУ УЧЕБНИКУ РУССКОГО ЯЗЫКА УНИВЕРСИТЕТСКОЙ ТУРИЗМОЛОГИЧЕСКОЙ СПЕЦИАЛЬНОСТИ И К УЧЕБНИКАМ ПОДОБНОГО ТИПА}

$$
\text { Резюме }
$$

В представленной работе рассматривается вопрос о семантической витальности (жизнеспособности) слов, т.е. их передвижение и преобразование из общего лексического запаса русского языка к запасу лексики туризмологического профиля. Таким образом, они находят применение в современных учебниках русского языка университетской туризмологической специальности.

Ключевые слова: семантическая витальность (жизнеспособность) слов и их преобразование, коммуникативная функция языка, общий лексический запас русского языка, словарь русского языка и словарный состав русского языка, сербский перевод слов, лексика туризмологического профиля, учебник русского языка университетской туризмологической специальности. 